\title{
Bridging The Gap Between Accounting Curriculum and Accounting Profession: Evidence from Jordan.
}

\author{
Dr. Osama Samih Shaban ${ }^{1}$ \\ ${ }^{1}$ Department of Accounting, Al-Zaytoonah University, Amman, Jordan \\ Correspondence: Dr. Osama Shaban, Department of Accounting, Al-Zaytoonah \\ University, Amman, PO Box 130 Amman 11733, Jordan.
}

\begin{abstract}
Educational institutions play an important role in preparing an individual to bear the burdens placed on him in order to contribute in the development process of his society and his nation. Universities are one of the most important educational institutions that play an active role an in preparing the specialized working power in various fields of life. The current research paper attempts to bridge the gap between accounting curriculum and accounting profession by analyzing the accounting curriculum adopted by the accounting department at Al-Zaytoonah university of Jordan, and to find out to what extent it matches with the international accounting standards, and finally developing a mechanism to harmonize the accounting curriculum with the international accounting standards.
\end{abstract}

Keywords: Modern Accounting Curriculum, Accounting Career, Accounting Profession, Accounting Techniques, International Accounting Standards. 


\section{Introduction:}

Educational institutions play an important role in preparing individual to bear the burdens placed on him in order to contribute in the development process of his society and his nation. Universities are one of the most important educational institutions that play an active role in preparing the specialized working power in various fields of life. The connection between accounting education and professional accountants is coined through an effective accounting curriculum which is capable of developing trained accountants as well as capable trained specialist accounting professionals.

In the year 2011 the UNCTAD published its revised detailed accounting curriculum which was accomplished by the efforts of many accounting experts around the globe. The purpose of the detailed curriculum is to describe for the international community the technical subject areas that an individual must master to become a professional accountant. The detailed curriculum is only one part of a larger exercise to create a benchmark for the qualifications of professional accountants which if followed would enable them to better function in and to better serve the global economy.

In the year 2015, O'Connel et. al, published the results of their project investigation of their multistakeholder investigation titled "Shaping the future of accounting in business education in Australia", the aim of their study was to assess the current state of play of accounting in business education in Australia. The key changes of the study focused on the issues and opportunities faced by the accounting education sector, and to develop feasible, innovative and productive ways forward to meet the many challenges faced by accounting education and to take full advantage of the opportunities identified. The key themes embraced in the investigation are as follows: professional knowledge and professional skills of accounting graduates; the inculcation of professional values, ethics and attitudes into graduates; scholarly research and its role in accounting education, creating knowledge and informing practice; and technology and innovation in learning environments. Their study presents the findings drawn from interviews with individuals who are engaged actively in graduate recruitment and the ongoing professional development of accountants. These interviewees were drawn from four key stakeholder groups comprising small, medium and large professional services firms, other employers of accounting graduates, regulators, including the major professional accounting bodies, and accounting academics. The key findings indicate that the future of accounting, like other facets of society, is being transformed by technology and the future of accounting work will advance into new areas while retaining broadly its fundamental core knowledge areas. New entrants into this field will need to possess well developed professional skills 
on their entry into the profession and, in combination with evolving professional knowledge and a solid core of professional values, ethics and attitudes. In addition, they need to have an ability to create value as business and wealth advisors, interpreters and communicators of financial and nonfinancial information, and contribute to the strategic direction of organizations, in particular, and society, in general. The findings of this investigation have resulted in the development of 17 recommendations designed to provide proactive strategies to meet the challenges presented and these are provided for higher education providers and accounting schools, employers, professional accounting bodies, and accounting student.

The objective of this paper is to discuss the gap between the accounting curriculum in the university or in the professional schools of business, and by the accounting profession, and trying to find a clear understanding of accounting knowledge and the profession, and by analyzing the accounting curriculum adopted by the accounting department at Al-Zaytoonah university of Jordan, and to find out to what extent it matches with the international accounting standards, and finally developing a mechanism to harmonize the accounting curriculum with the international accounting standards. The current problem is the gap between the accounting curriculum in the university or in the professional schools of business and the accounting profession. This gap is increasing due to increasing demand dominated by the focusing effect by the preparation for the certified professional exams such as CPA, and CMA or the widespread importance exerted by opportunities in tax and government accounting. And all of these forces are driven by the importance of the livelihood furnished opportunities of getting immediate employment.

\section{Analysis of the Accounting Curriculum at Al-Zaytoonah University of Jordan: The} department of accounting was established in the academic year 1993 / 1994. The department has 23 faculty members and teaches 1170 students. The department has graduated 23 groups of alumni, with 23 of these being bachelor degree holders and 7 of these being master degree holders. The department faculty has produced 138 texts of scientific research published in internationally renowned journals. The faculty has also participated in 72 international scientific conferences both locally and internationally. The components of the accounting curriculum of the accounting department being analyzed were updated on the academic year 2017/2018, and it was approved by dean's council on 
$30^{\text {th }}$ August 2017. The heading of the accounting curriculum is addressed by the expected goals and followed by the intended learning outcomes of each goal as follows:

1. Provide students with scientific and practical knowledge in various accounting fields. The student will be able to

- Demonstrate knowledge in various accounting areas.

- Understand the principles, values, ethical, regulatory, social, professional and legal responsibilities for accounting issues

- Communicate effectively in various accounting fields

2. Develop the students' abilities in research and critical thinking, and apply them in the field of work. The student will be able to

- Effectively apply accounting knowledge and skills in the functional areas of business

- Apply critical thinking skills by solving accounting problems requiring quantitative and/or qualitative analysis.

3. Inform students of methods to record, audit, analyze, and use accounting information, and provide them with the necessary expertise to innovate and keep up with accounting developments. The student will be able to

- Use information technology to accomplish specific purposes in accounting

- Demonstrate the skills of being part of a team in various accounting fields Understand the recent methods in various accounting fields.

4. Provide students with research, analysis, reasoning and accounting problem-solving capabilities. The student will be able to

- Use scientific research tools to collect and analyze accounting data in the field of work.

- Understand the skills of deduction and finding solutions related to accounting problemsolving in the field of work.

The accounting bachelor program curriculum is formed out of 132 credit hours, and it is divided into three main categories as follows:

1. Major requirements (81) credit hours. These requirements compose the main accounting subjects required to fulfill professional knowledge and professional skills of the accounting graduates, and it is subdivided into three groups:

- Mandatory major requirements (54) credit hours.

- Major supporting requirements (18) credit hours. 
- Major elective (9) credit hours.

2. University requirements (27) credit hours. These requirements provide the accounting graduates of the general knowledge and life skills, and it is subdivided into two groups:

- Mandatory requirements (15) credit hours.

- Elective requirements (12) credit hours.

3. Faculty requirements (24) credit hours. These requirements are the supporting subjects within the faculty of business required to fulfill the organizational and business knowledge. The objectives of these requirements are to provide candidates with an understanding of the issues, concepts and theories of microeconomics, macroeconomic, principles of management and marketing, business statistics and mathematics, and principles of management information system.

As the importance of accounting grows in today's world, so does the need for a solid background and a high level of understanding of both the theory and practice of accounting. Accounting education is important and it can be applied to any job industry, and as the aim of this paper is bridge the gap between the accounting curriculum in the universities and the accounting profession, and to find out to what extent the accounting curriculum matches with the international accounting standards being actually practiced. Higher education in Jordan believed that the implementation of a unified set of standards will enable Jordan to be one of the leading countries in this field. This goal has attracted Jordan to embark on the adoption of IFRS in the year 2012 along with other 122 countries around the world, and it has been integrated fully in AlZaytoonah University in particular and in higher Jordanian education curriculum in general since that time. The adoption of IFRS has implications for the accounting profession and accounting education in Jordan. Identifying these implications is important for preparing accounting graduates with the required knowledge for the efficient and effective transition to IFRS, such as promoting higher quality financial reporting and rethinking accounting education in terms of curriculum and classroom interaction (Sunder, 2010).

\section{Harmonization of accounting standards}

Harmonization of accounting standards has become a highly demanded issue of discussion and debate among accounting professionals around the globe. Accounting Standards are the authoritative statements of best accounting practices issued by recognized expert accountancy bodies relating to various aspects of measurements, treatments and disclosures of accounting 
transactions and events, as related to the codification of Generally Accepted Accounting Principles (GAAP) (Shil et. al., 2009). These are stated to be the norms of accounting policies and practices by way of codes or guidelines to direct as to how the items, which make up the financial statements, should be dealt with in accounts and presented in the annual accounts. In fact, such statements are designed and prescribed to improve and benchmark the quality of financial reporting. They bring about uniformity in financial reporting and ensure consistency and comparability in the data published by enterprises. These are aimed at furnishing useful information to different users of the financial statements, such as shareholders, creditors, lenders, management, investors, suppliers, competitors, researchers, regulatory bodies and society at large. The process of harmonization gives the global community a single entity. The diversity of stockholding doesn't matter today if the accounting system can generate general purpose financial statements in real sense. Hence, the need for harmonization of accounting standards has been strongly advocated globally in order to faster the economic decisionmaking process. Accounting has already bagged the status of the' language of the business' that requires reporting of the affairs in a commonly understandable way. At the World Bank Conference held in 1999, Jules W. Muis aptly states

"power to control the language of business is important. Standard setters will come ahead as the world grows smaller, and economic independence is no longer an option but a reality. So it happens that today a good observer can see the preparations of battle for the control of the international language of business slowly unfolds..." In this context, the statement of Harvey Pitt, US SEC Chairman at SEC Conference, (2002) is worth mentioning, "High quality global accounting standards are needed to improve the ability of investors to make informed financial decisions. Companies must keep pace with this progress in order to promote and protect their business credibility in the international market place." It is for this reason that the convergence of accounting standards is so important. The process of convergence is accepted as the key factor to implement a single set of accounting standards across the globe (Rezaee \& Szendi, 2010).

\section{Rationales of Harmonization of Accounting Standards}

To allow the gains from the global economy to be fully realized, it is argued that accounting policy should be standardized among nations. This "harmonization" of accounting standards will help the world economy in the following ways: 
- Facilitating international transactions and minimizing exchange costs by providing increasingly "perfect" information.

- Standardizing information to world-wide economic policy-makers.

- Improving financial markets information.

- Improving government accountability.

However, harmonization of accounting policy would help provide a "level playing field" globally. Regulators and auditors will be receiving the same information, facilitating the evaluation process. In the absence of free trade, international accounting standards will allow nations' tariffs, quotas and other trade restraint mechanisms to be more accurate and less risky for those engaged in trade. Investors and managers will be able to make more valuable decisions. World resources will be better managed and allocated. The recent expansion of international capital markets and availability of instantaneous global communication have placed on accounting the onus to provide useful and comparable information across international borders (Rivera, 1989).

Harmonization is not an end by itself, but it is a means to an end. Adoption of different accounting standards causes difficulties in making relative evaluation of performance of companies. This phenomenon hinders the valuation and consequently the decision making process. Another significant benefit that is expected to accrue from global convergence of accounting standards relates to cross-border mergers and acquisitions facilitation. Last though not the least, it improves the quality of financial reporting throughout the globe. Conclusion: The international harmonization of Accounting Standards is a process, which brings international Accounting Standards into some sort of agreement, in order to achieve a common set of accounting principles.

The harmonization of accounting practices suffers from a lack of synchronization between the issuance of standards at the national level in different countries and the formulation of standards by the various accounting foundations. As we know that it is an age of globalization, there is no conceptual boundary among the nations. And this is not difficult at all to choose superior standards through the current process of setting the standards. The attainment of a single set of accounting and reporting standards is the demand of the time. We will fall behind if this harmonization process takes more time. Many of the initial hurdles in the process of harmonization have been overcome and much progress towards convergence of accounting principles and 
procedures among countries has already been achieved. Convergence initiatives are now working much more effectively than ever before. Differences are still there but they are narrowing. It is expected that the pace of progress in the sphere of convergence will accelerate further in the coming years. Setting IFRS under new regulatory framework is also a notable success in harmonization. IAS permits some alternative practices that has been reduced in IFRS to make the prescription common to all so that following same standards cannot generate varying practices. We expect that this process will ultimately set new benchmark for achieving harmonization in both national and international level.

\section{References:}

Hicks, O 2007, 'Curriculum in higher education in Australia-Hello', in Enhancing Higher Education, Theory and Scholarship, Proceedings of the 30th HERDSA Annual Conference, Adelaide, 8-11 July.

O’Connel, Brendan, Garry D. Carnegie, Amanda J. Carter, Paul de Lange Curtin, Phil Hancock, Christine V. Helliar, Kim Watty Deakin. (2015), "Shaping the future of accounting in business education in Australia". Published by CPA Australia, Melbourne, Australia

Rezaee,Z., Smith, L.M, Szendi, J.Z., (2010), Convergence in accounting standards: Insights from academicians and practitioners, Advances in Accounting, incorporating Advances in International Accounting, no. 26, p. 142-154

Rivera, J. M. (1989). The Internationalization of Accounting Standards: Past Problems and Current Perspectives. International Journal of Accounting, 24(4), 320-342.

Shil, C.Nikhil, Das, Bhagaban, Pramanik, K.Alok, (2009), "Harmonization of Accounting Standards through Internationalization”, International Business Research, Vol.2, No.2.

Sunder, S 2010, 'Adverse effects of uniform written reporting standards on accounting practice, education, and research', Journal of Accounting and Public Policy, vol. 29, no. 2, pp. 99-114.

UNCTAD, (2011)," Model Accounting Curriculum (Revised)" UNCTAD/DIAE/MISC/2011/ 1 
$5^{\text {th }}$ International Conference on New Ideas in Management, Economics and Accounting 